\title{
Implementasi Manajemen Pendidikan Berbasis Masyarakat dalam Penjaminan Mutu Pendidikan Anak Usia Dini
}

\author{
Undang Ruslan Wahyudin ${ }^{1 凶}$ \\ Pendidikan Agama Islam, Universitas Singaperbangsa Karawang, Indonesia(1) \\ DOI: $\underline{10.31004 / o b s e s i . v 6 i 2.1357}$
}

\begin{abstract}
Abstrak
Penelitian ini bertujuan untuk mengetahui informasi secara lebih jauh mengenai implementasi manajemen pendidikan berbasis masyarakat dalam penyelenggaraan penjaminan mutu pendidikan anak usia dini. Metode yang dilakukan dalam penelitian ini adalah deskriptif dengan pendekatan kualitatif. Teknik pengumpulan data yang digunakan adalah wawancara dan studi dokumentasi. Hasil penelitian menunjukkan bahwa di RA Al-Hilal Cikarang sangat dipengaruhi oleh pelibatan masyarakat / partisipasi masyarakat yang dijadikan pendekatan melalui dua strategi utama yaitu budaya transparansi pengelolaan sumber daya pendidikan dan penerapan budaya akuntabilitas dalam penyelenggaraan pengelolaan pendidikan berbasis masyarakat pada penjaminan mutu Pendidikan Anak Usia Dini.
\end{abstract}

Kata kunci : manajemen pendidikan berbasis masyarakat; penjaminan mutu; pendidikan anak usia dini.

\begin{abstract}
This study aims is to find out more information about the implementation of community-based education management on conducting the quality assurance in early childhood education. The method performed in the study is descriptive of qualitative approach. The data collecting technique used is interview and documentation study. The result of the study indicates that in RA Al Hilal Cikarang is strongly influenced by the involvement of community/public participation is an approach conducted through two main strategies such as the culture of transparency on managing educational resources and implementing the culture of accountability on the implementation of community-based education management on quality assurance of the early childhood education.
\end{abstract}

Keywords: community-based educational management; quality assurance; early childhood education.

Copyright (c) 2021 Undang Ruslan Wahyudin

$\triangle$ Corresponding author:

Email Address : urwahyudn@fai.unsika.ac.id (Karawang, Jawa Barat, Indonesia)

Received 13 January 2021, Accepted 22 June 2021, Published 23 June 2021 


\section{PENDAHULUAN}

Kebijakan paudisasi desa melalui Program 1 Desa 1 PAUD yang digulirkan pada tahun 2012 sebagai salah satu upaya perluasan dan pemerataan akses dalam rangka peningkatan Angka Partisipasi Kasar (APK) Pendidikan Anak Usia Dini (PAUD), dapat dikatakan telah berhasil mendongkrak pertumbuhan PAUD di tanah air (Kementerian Pendidikan dan Kebudayaan, 2018). Buktinya di mana-mana baik di wilayah perkotaan maupun pedesaan banyak didirikan sehingga saat ini mudah ditemukan satuan pendidikan formal dan nonformal dalam berbagai jenis seperti Taman Kanak (TK), Raudatul Athfal (RA), Kelompok Bermain (KB), Bustanul Athfal (BA), Taman Penitipan Anak (TPA) dan Satuan PAUD Sejenis (SPS) (Permana \& Syafrida, 2019). Artinya jumlah satuan pendidikan jenjang ini mengalami peningkatan tajam pada beberapa tahun terakhir.

Keberhasilan dalam mendongkrak pertumbuhan jumlah satuan pendidikan dalam rangka peningkatan APK PAUD sebagai mana dikemukakan di atas kelihatannya masih menyisakan banyak permasalahan mendasar (Permana \& Syafrida, 2019). Salah satu permasalahan dimaksud adalah mengenai kualitasnya yang dianggap belum seperti yang diharapkan. Artinya keberhasilan tersebut tidak serta merta berbanding lurus dengan kesuksesan dalam peningkatan mutunya. Bahkan kenyataannya hingga saat ini mutu PAUD masih menjadi permasalahan aktual yang belum terpecahkan secara tuntas, disamping permasalahan pendidikan lainnya. Dengan kata lain masih terjadi ketimpangan antara pemerataan akses dengan peningkatan mutunya sehingga memerlukan keseriusan berbagai pihak untuk mengatasinya.

Sebenarnya berbagai upaya telah dilakukan untuk memecahkan masalah mutu pendidikan dimaksud. Salah satu di antaranya yang dianggap sangat mendasar dan strategis adalah dikeluarkannya kebijakan mengenai pemberlakuan Peraturan Pemerintah Nomor 32 Tahun 2013 Tentang Perubahan Atas Peraturan Pemerintah nomr 19 tahun 2005 tentang Standar Nasional Pendidikan. Bahkan sebagai penjabaran dan merupakan turunan dari peraturan pemerintah tersebut di atas, secara teknis operasional telah diterbitkan Peraturan Menteri Pendidikan dan Kebudayaan nomor 137 tahun 2014 tentang Standar Nasional Pendidikan Anak Usia Dini (PAUD) yang meliputi: Standar Tingkat Pencapaian Perkembangan Anak Usia Dini (STPPA), standar isi, standar proses, standar penilaian, standar pendidik dan tenaga kependidikan, standar pengelolaan,standar sarana dan prasarana, serta standar pembiayaan. Di dalam peraturan tersebut telah dimuat secara rinci berbagai karakteristik yang merupakan standar minimal yang harus dipenuhi semua satuan PAUD baik pada jalur formal maupun nonformal.

Meskipun kebijakan ini bersifat mengikat yaitu memaksa semua lembaga layanan pendidikan di tanah air untuk melakukan upaya penyesuaian dengan acuan mutu di atas, namun kenyataannya secara umum belum berhasil seperti yang diinginkan. Bahkan disinyalir masih terjadi kesenjangan antara kuantitas dan kualitasnya. Artinya bahwa setiap satuan pendidikan pada jenjang ini masih harus melakukaan berbagai Langkah konkrit agar dapat menyediakan layanan pendidikan sesuai dengan kriteria minimal sebagaimana tertuang dalam peraturan tersebut. Oleh karena itu masih perlu adanya pedoman sebagai panduan dalam pelaksanaannya (Handoko, 2011).

Untuk menjamin keterlaksanaan peraturan di atas, maka pemerintah telah mengeluarkan kebijakan mengenai sistem penjaminan mutu Pendidikan berdasarkan peraturan Menteri Pendidikan dan Kebudayaan nomor 28 tahun 2016 (Budiyanti et al., 2021). Di sini ditegaskan bahwa penjaminan mutu Pendidikan dasar dan menengah dilakukan melalui suatu pendekatan yang komprehensif dengan melibatkan para unsur tekait, yaitu Sistem Penjaminan Mutu Internal (SPMI) atau system penjaminan mutu pendidikan oleh satuan Pendidikan yang bersangkutan dan Sistem Penjaminan Mutu Eksternal (SPME) yaitu pelaksanaan penjaminan mutu Pendidikan oleh pemerintah, pemerintah daerah, Lembaga akreditasi, dan Lembaga standarisasi Pendidikan yang ditentukan (Yanto, 2020). 
Pelaksanaan sistem penjaminan mutu internal (SPMI) pada tingkat satuan pendidikan melibatkan seluruh pemangku kepentingan (stakehoders) yaitu unsur pendidik, tenaga kependidikan, peserta didik, dan masyarakat (Yusutria, 2019). Pelibatan para unsur tersebut dalam hal ini sangat penting sebagai wujud pengelolaan pendidikan yang transfaran dan akuntabel dalam melaksanakan Manajemen Berbasis Sekolah dan masyarakat (Ruslan Wahyudin \& Permana, 2020). Hal ini tentu saja tidak terlepas dari pengaruh proses reformasi yang terjadi dalam bidang pendidikan yang sekarang menganut pola desentralisasi dan otonomi yaitu memposisikan unsur yang ada di satuan pendidikan dan masyarakat sebagai actor utama penentu arah kebijakan pengelolaan pendidikan di lingkungannya (Firman, 2018).

Pelibatan masyarakat dalam penjaminan mutu pendidikan ini dipandang sangat penting di tengah kondisi adanya keterbatasan kemampuan pemerintah dalam menjalankan kewajibannya yaitu menyediakan layanan pendidikan yang berkualitas (Baharun et al., 2021). Pandangan ini sudah pasti sejalan dengan paradigma baru pengelolaan pendidikan di Indonesia. Sebagaimana diketahui bahwa telah terjadi reformasi total dalam pengelolaan Pendidikan dasar dan menengah dari yang semula berbasis pemerintah (state-based education) menjadi berbasis satuan pendidikan yang dikenal sebaga Manajemen Berbasis Sekolah (Scool Based Manajement) dan berbasis masyarakat atau disebut Pendidikan Berbasis Masyarakat (Community-Based Education). Artinya masyarakat diposisikan sebagai pihak yang harus ikut memikul tanggung jawab dalam keterlaksanaan layanan pendidikan sesuai standar yang ditentukan. Hal ini sejalan dengan pendapat yang dikemukakan Machali dan Hidayat (2016: 354) bahwa masyarakat memiliki peran sentral dan strategis dalam penyelenggaraan layanan Pendidikan pada tingkat satuan Pendidikan.

Pendidikan berbasis masyarakat merupakan proses pendidikan yang mengedepankan kontrol masyarakat local melalui partisipasi demokratis. Pendidikan berbasis masyarakat pada prinsipnya Pendidikan yang dirancang, diatur, dilaksanakan, dinilai dan dikembangakan oleh masyarakat (Supriadi, 2001). Undang undang system Pendidikan nasional mengamanatkan bahwa pendidikan diselenggarakan dengan memberdayakan semua komponen masyarakat melalui peran serta dalam penyelenggaraan dan pengendalian mutu layanan pendidikan (Dwikurnaningsih, 2020). Menurut Resbin L. Sihite peran serta masyarakat dalam pendidikan meliputi: sebagai sumber Pendidikan, Sebagai pelaku Pendidikan, Pelaksana pendidikan, pengguna hasil Pendidikan, perencanaan Pendidikan, pengawasan Pendidikan, dan evaluasi program pendidikan (Wahyudin et al., 2021).

Agar pendidikan berbasis masyarakat berfungsi secara optimal, perlu dikelola dengan baik melalui manajemen yang efektif . Manajemen menurut Terry merupakan suatu proses khas yang terdiri dari tindakan-tindakan perencanaan, pengorganisasian, penggerakan dan pengendalianyang dilakukan untuk menentukan serta mencapai sasaran yang telah ditentukan melalui pemanfaatan sumberdaya manusia dan sumber daya lainnya. Sementara itu menurut Robbins dan Coulter proses manajemen merupakan srangkaian dan kegiatan kerja terus menerus yang dialami para manajer sewaktu mereka merancang, mengorganisasi, memimpin, dan mengendalikan. Berdasarkan uraian di atas maka manajemen pendidikan berbasis masyarakat tidak lain merupakan proses pelibatan partisipasi masyarakat dalam pengelolaan pendidikan mulai dari perencanaan, pelaksanaan, dan pengawasan atau pengendaliannya, dengan tujuan utama utuk memberikan layanan pendidikan terbaik sesuai kebutuhan masyarakat (Ruslan Wahyudin \& Permana, 2020) .

Penelitian ini bertujuan untuk memperoleh informasi mengenai pendekatan dan strategi yang digunakan dalam implementasi manajemen pendidikan berbasis masyarakat dalam penjaminan mutu Pendidikan Anak Usia Dini yang dituangkan dalam rumusan masalah yaitu Bagaimana implementasi manajemen pendidikan berbasis masyarakat dalam penjaminan mutu Pendidikan Anak Usia Dini sehingga menemukan sebuah strategi dalam mengimplementasikan manajemen pendidikan berbasis masyarakat dalam penjaminan mutu pendidikan anak usia dini. 


\section{METODOLOGI}

Penelitian ini menggunakan metode deskriptif dengan pendekatan kualitatif untuk mengungkap pakta apa adanya secara realistis tentang penjaminan mutu Pendidikan di Raudhatul Athfal (RA) Alhilal. Pengumpulan datanya dilakukan dengan menggunakan instrument wawancara dan studi dokumentasi. Informan dalam penelitian adalah kepala sekolah dan 6 orang guru di Raudhatul Athfal (RA) Alhilal juga masyarakat yang merupakan pemangku kepentingan lembaga yang bersangkutan. Sedangkan studi dokumentasinya dilakukan terhadap profil, photo-photo kegiatan tertentu, dan dokumen yang relevan di Raudhatul Athfal (RA) Alhilal. Penelitian dilakukan selama 4 bulan, dimulai dari bulan Januari 2021 sampai April 2021. Analisis data penelitian yang dilakukan dalam penelitian ini adalah dengan cara analisis kasus tunggal yaitu dimulai dari penentuan subjek penelitian, penentuan sumber data, pengumpulan data, analisis data, penarikan reduksi data, penarikan kesimpulan dan penyusunan laporan hasil penelitian tentang manajemen pendidikan di RA Al-Hilal dalam penjaminan mutu pendidikan anak usia dini. Untuk lebih rincinya tahapan penelitian dapat dilihat pada gambar 1 .

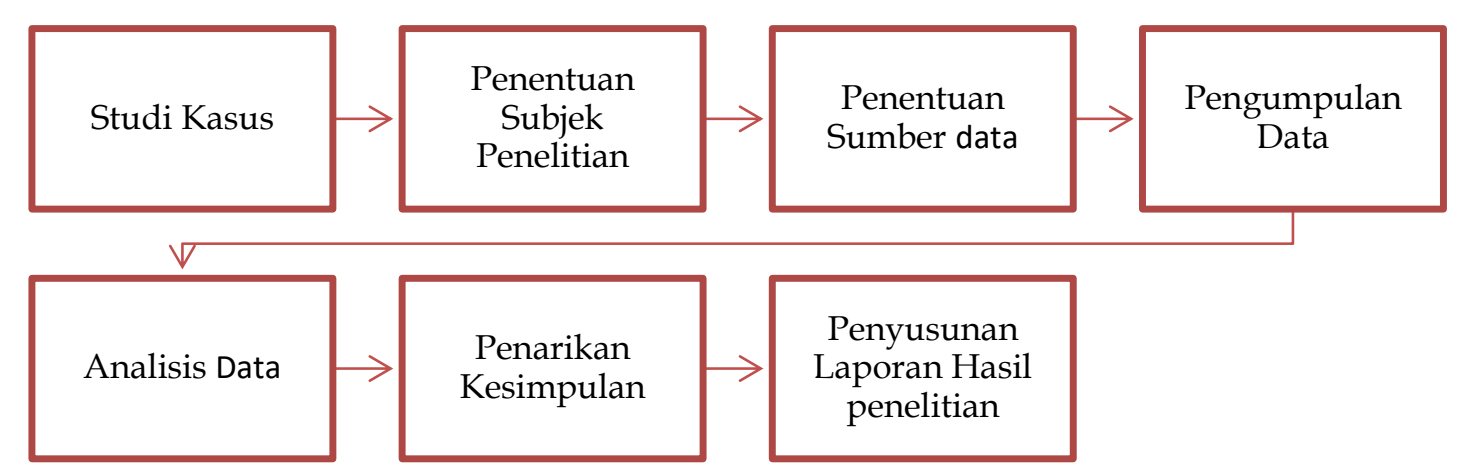

Gambar 1. Tahapan Penelitian

\section{HASIL DAN PEMBAHASAN}

Berdasarkan hasil analisis data dari kegiatan wawancara dan studi dokumentasi maka secara faktual Raudatul Athfal (RA) Alhilal Cikarang merupakan lembaga Pendidikan Anak Usia Dini berbasis masyarakat. Terdapat sejumlah argumen yang mendasari dan mendukung pandangan di atas. Pertama, berdasarkan hasil penelusuran mengenai riwayat kelahirannya, pendirian satuan pendidikan tersebut sepenuhnya digagas dan diprakarsai oleh para tokoh yang tergabung pada Yayasan Pendidikan Islam Mutiara Bangsa dengan dukungan dari warga masyarakat setempat. Arinya satuan pendidikan ini lahir dari masyarakat. Inilah salah satu ciri pendidikan berbasis dalam konteks pendidikan nasional adalah pendidikan yang diberikan oleh sekolah swasta atau Yayasan (Supriadi, 2001).

Kedua, proses kegiatan pendidikannya bertumpu kepada dukungan masyarakat lokal dan senantiasa memanfaatkan berbagai potensi sumber daya yang ada di lingkungannya. Artinya bahwa lembaga lembaga pendidikan tersebut lahir dari masyarakat dan dikelola oleh masyarakat. Ketiga tujuan utama pendiriannya adalah guna memenuhi kebutuhan warga masyarakat, terutama yang mengalami kesulitan dalam memperoleh akses layanan pendidikan usia dini yang disebabkan persoalan jarak geografis, keterbatasan daya jangkau secara ekonomis dan lain-lain. Berarti institusi pendidikan tersebut disediakan untuk masyarakat sekitarnya. Keempat, proses pengelolaannya dilakukan secara demokratis dan banyak melibatkan partisipasi warga lokal. Artinya dalam proses manajerialnya banyak melibatkan peran masyarakat. Oleh karena itulah maka tidak berlebihan kalau dianggap bahwa di sini sangat kental adanya implementasi manajemen pendidikan berbasis masyarakat. Hal ini merujuk kepada konsep manajemen pendidikan berbasis masyarakat 
yang dikemukakan Winarno Surahmad bahwa pendidikan berbasis masyarakat adalah model penyelenggaraan Pendidikan dari masyarakat, oleh masyarakat, dan untuk masyarakat (Zubaidi, 2005).

Pelaksanaan manajemen pendidikan berbasis masyarakat di sini secara praktis ditandai dengan pelibatan partisipasi masyarakat dalam seluruh proses pengelolaan pendidikan mulai dari tahap perencanaan (planning), pengorganisasian (organizing), penggerakan (actuating), dan pengawasannya (controlling) (Ruslan Wahyudin \& Permana, 2020). Pelibatan unsur masyarakat dalam hal ini antara lain ditunjukkan melalui keikutsertaannya dalam pengambilan keputusan, ambil peran dalam pemberian dukungan pemenuhan kebutuhan sumber daya yaitu dikenal dengan $5 \mathrm{M}$ (man, materials, machines, methods, dan money). Selain itu masyarakat kerap kali berperan selaku pendamping dan pelaksana kegiatan, dan sebagai pengawas baik langsung atau tidak langsung dalam penggunaan sumber daya pendidikan .

Indikator Pelibatan Peran serta Masyarakat dalam Pengelolaan RA Al Hilal dapat dilihat pada tabel 1.

Tabel 1. Indikator Pelibatan Peran serta Masyarakat dalam Pengelolaan RA Al Hilal

\begin{tabular}{cccc}
\hline $\begin{array}{c}\text { Perencanaan } \\
\text { (planning) }\end{array}$ & $\begin{array}{c}\text { Pengorganisasian } \\
\text { (organizing) }\end{array}$ & $\begin{array}{c}\text { Penggerakan } \\
\text { (actuating) }\end{array}$ & Pengawasan (controlling) \\
\hline Unsur masyarakat & Masyarakat ambil & Unsur & Masyarakat memantau \\
ikut serta dalam & peran dalam & masyarakat & penggunaan sumber daya \\
pengambilan & pemberian dukungan \\
keputusan & pemelaksanaan \\
& daya pendidikan & $\begin{array}{c}\text { pendampingan } \\
\text { dalam kegiatan } \\
\text { di luar sekolah }\end{array}$ & pendidikan \\
& & & \\
\hline
\end{tabular}

Terkait dengan manajemen mutu, sangat kental kelihatan adanya pelibatan partisipasi masyarakat yang merupakan essensi dari community-based education. Bahkan dapat dikatakan bahwa pelibatan partisipasi masyarakat benar-benar dijadikan pendekatan utama dalam pelaksanaan penjaminan mutu di satuan pendidikan ini. Penggalian potensi local dilakukan secara optimal dalam rangka pemenuhan delapan standar nasional, sebagaimana ketentuan yang tertuang dalam Peraturan Menteri Pendidikan dan Kebudayaan nomor 137 tahun 2014 tentang Standar Nasional Pendidikan Anak Usia Dini yang meliputi: Standar Tingkat Pencapaian Perkembangan Anak Usia Dini (STPPA), standar isi, standar proses, standar penilaian, standar pendidik dan tenaga kependidikan, standar pengelolaan,standar sarana dan prasarana, serta standar pembiayaan. Hal ini mengacu kepada petunjuk pelaksanaan penjaminan mutu pendidikan oleh satuan pendidikan berdasarkan Peraturan Menteri Pendidikan dan Kebudayaan nomor 28 tahun 2016 yang menyatakan bahwa penjaminan mutu pendidikan bertujuan untuk memenuhi atau melampaui Standar Nasional Pendidikan. Selain itu Peranan guru yaitu sebagai sentral dalam berbagai kegiatan interaksi belajar mengajar (Maiza \& Nurhafizah, 2019).

Secara lebih rinci, optimalisasi pelibatan partisipasi masyarakat dalam pelaksanaaan penjaminan mutu dimaksud dapat dijelaskan sebagai berikut. Pertama, pelibatan partisipasi masyarakat dalam pencapaian STPPA adalah suatu kenyataan yang tidak terbantahkan. Artinya tidak dapat dipungkiri adanya peran masyarakat yang sangat besar, sangat dominan dan sangat mentukan dalam mewujudkan mutu yang sesuai dengan kriteria yang terdapat pada STPPA yang telah ditetapkan. Secara konkrit dapat diambil salah satu contoh yaitu ketika melaksanakan kegiatan dalam rangka pencapaian pertumbuhan dan perkembangan peserta didik sebagaimana digariskan dalam Standar PAUD, yang merupakan integrasi dari perkembangan aspek nilai agama dan moral, fisik-motorik, kognitif, bahasa, dan sosialemosional, serta seni dan juga merupakan perubahan perilaku yang berkesinambungan dan terintegrasi dari faktor genetik dan lingkungan serta meningkat secara individual baik 
kuantitatif maupun kualitatif. Hal ini sangat sejalan dengan semangat yang terdapat pada Standar PAUD yang menyatakan bahwa STPPA adalah Pencapaian pertumbuhan dan perkembangan anak yang optimal membutuhkan keterlibatan orang tua dan orang dewasa serta akses layanan PAUD yang bermutu (Syafrida et al., 2020).

Kedua, pelibatan peran serta masyarakat dalam pemenuhan standar isi diwujudkan saat melakukan pengembangan kurikulum. Hal ini perlu dijelaskan bahwa kurikulum di RA Alhilal didesain oleh tim pengembang yang dibentuk satuan pendidikan dengan berpedoman kepada standar yang berlaku. Ruang lingkup materinya meliputi program pengembangan yang disusun sesuai dengan karakteristik, kebutuhan, tahap perkembangan anak, dan budaya local. Semua materi dimaksud dirumuskan secara sistematis dan dituangkan dalam sebuah dokumen tertulis yang dievaluasi dan ditinjau ulang secara berkala sesuai kebutuhan dalam rangka penyesuaian dengan perkembangan yang terjadi pada tingkat local, nasional, dan global. Hasil evaluasi dimaksud dijadikan dasar pertimbangan dalam pengembangannya dengan melibatkan berbagai unsur pemangku kepentingan dan para pengguna jasa layanannya (user) yang dalam hal ini tentu saja termasuk warga masyarakat selaku pihak yang berkepentingan (Zulkarnain et al., 2020). Masyarakat di sini memberikan masukan baik pada proses perumusan, evaluasi, dan pengembangannya mengenai berbagai kompetensi dan perilaku yang diperlukan peserta didik dalam mempersiapkan diri untuk menghadapi kehidupannya saat ini dan proyeksinya dimasa yang akan datang.

Ketiga, adanya pelibatan partisipasi masyarakat dalam pemenuhan standar proses tidak dipungkiri. Hal ini tentu saja menjadi fakta yang menghapus anggapan yang selama ini dipersepsikan bahwa seolah-olah proses pembelajaran sepenuhnya menjadi ranah para pendidik, namun sesuai dengan peradigma baru pengelolaan pendidikan era desentralisasi berupa penerapan konsep manajemen berbasis sekolah yang membuka ruang bagi pelibatan peran serta masyarakat dalam keseluruhan pengelolaan pendidikan, dan dalam rangka penjaminan mutu demi keterlaksaan sesuai standar proses yang tertuang dalam standar nasional PAUD, masyarakat turut berperan dalam mengawal pelaksanaan proses pembelajaran di RA Alhilal Cikarang yang sudah barang tentu tanpa adanya intervensi terhadap otoritas para pendidik.

Pengawasan dimaksud dilakukan melalui control agar proses pembelajaran yang meliputi perencanaan pembelajaran, pelaksanaan pembelajaran, evaluasi pembelajaran dan pengawasan pembelajaran benar-benar mengacu dan sesuai dengan kriteria yang terdapat pada standar nasional PAUD, dan pendekatannya sesuai dengan kentuan yaitu dilakukan melalui bermain secara interaktif, inspiratif, menyenangkan, kontekstual dan berpusat pada anak untuk berpartisipasi aktif serta memberikan keleluasaan bagi prakarsa, kreativitas, dan kemandirian sesuai dengan bakat, minat, dan perkembangan fisik serta psikologis anak (Utami et al., 2019). Bahkan masyarakat yang dalam hal ini diperankan oleh para orang tua peserta didik lebih banyak terlibat langsung dalam proses pengasuhan terutama ketika melaksanakan kegiatan ekstrakurikuler yang dilakukan secara berkala di luar lingkungan sekolah. Dalam hal ini bahkan sangat sering masyarakat bukan hanya bertindak sebagai pembimbing atau pendamping melainkan justru perperan selaku pemrakarsa atau menjadi panitia pelaksana kegiatanya. Setelah melakukan kegiatan pembelajaran evaluasi dibutuhkan untuk mengetahui keberhasilan atau ketercapaian tujuan pembelajaran yang ditatapkan (Idhayani et al., 2020).

Keempat, pelibatan partisipasi masyarakat dalam pemenuhan standar penilaian memang ada meskipun sangat terbatas terutama dimaksudkan agar proses penilaian benarbenar berjalan dengan berpedoman kepada standar yang telah ditentukan, yaitu kriteria tentang penilaian proses dan hasil pembelajaran dalam rangka mengetahui tingkat pencapaian yang sesuai dengan tingkat usia anak. Hasilnya menunjukkan bahwa penilaian di sini sudah sesuai dengan kriteria dimaksud yaitu meliputi prinsip penilaian, teknik dan instrumen penilaian, mekanisme penilaian, pelaksanaan penilaian, dan pelaporan hasil penilaian. Prinsip penilaian mencakup prinsip edukatif, otentik, obyektif, akuntabel, dan 
transparan yang dilakukan secara terintegrasi, berkesinambungan, dan memiliki kebermaknaan. Prinsip edukatif merupakan penilaian yang mendorong anak meraih capaian perkembangan yang optimal. Prinsip otentik merupakan penilaian yang berorientasi pada kegiatan belajar yang berkesinambungan dan hasil belajar yang mencerminkan kemampuan anak saat melaksanakan kegiatan belajar. Prinsip objektif merupakan penilaian yang didasarkan pada indikator capaian perkembangan serta bebas dari pengaruh subjektivitas penilai dan yang dinilai. Prinsip akuntabel merupakan pelaksanaan penilaian sesuai dengan prosedur dan kriteria yang jelas, serta ditetapkan pada awal pembelajaran. Prinsip transparan merupakan penilaian prosedur dan hasil penilaian yang dapat diakses oleh semua pemangku kepentingan. Teknik penilaian sesuai dengan tingkat pencapaian perkembangan anak. Instrumen penilaian terdiri atas instrumen penilaian proses dalam bentuk catatan menyeluruh, catatan anekdot, rubrik dan/atau instrumen penilaian hasil kemampuan anak. Keefektifan proses pembelajaran akan terjalin apabila terdapat komunikasi antara media penyalur pesan dengan penerima pesan (Safitri et al., 2020).

Sementara itu, hasil akhir penilaian merupakan integrasi antara berbagai teknik dan instrumen penilaian yang digunakan. Mekanisme penilaian terdiri atas: menyusun dan menyepakati tahap, teknik, dan instrumen penilaian serta menetapkan indikator capaian perkembangan anak; melaksanakan proses penilaian sesuai dengan tahap, teknik, dan instrumen penilaian; mendokumentasikan penilaian proses dan hasil belajar anak secara akuntabel dan transparan; dan melaporkan capaian perkembangan anak pada orang tua. Pelaksanaan penilaian dilakukan menggunakan mekanisme yang sesuai dengan rencana penilaian.. Pelaporan hasil penilaian berupa deskripsi capaian perkembangan anak. Deskripsi capaian perkembangan anak berisi tentang keistimewaan anak, kemajuan dan keberhasilan anak dalam belajar, serta hal-hal penting yang memerlukan perhatian dalam pengembangan diri anak selanjutnya. Pelaporan penilaian disusun secara tertulis sebagai bentuk laporan perkembangan belajar anak. Hasil penilaian dalam bentuk laporan perkembangan anak disampaikan kepada orang tua dalam kurun waktu semester. Hasil penilaian ditindaklanjuti dalam kegiatan berikutnya.

Kelima, tampak jelas adanya pelibatan partisipasi masyarakat dalam pemenuhan standar pendidik dan tenaga kependidikan di sini. Dilihat dari pola pengelolaan sumber daya manusia pendidikan, dapat dipastikan bahwa RA Alhilal mengandalkan masyarakat sebagai sumber utama dalam rekruitmen dan pengembangan pendidik dan tenaga kependidikan guna memenuhi kebutuhan baik kuantitas maupun kualitasnya. Walau pun ada peran pemerintah namun hanya pada batas batas tertentu, terutama dalam hal pembinaan dan pengawasan sesuai dengan fungsi dan kewenangannya. Pelaksanaan rekruitmen dan seleksi dilakukan secara terbuka melalui kolaborasi antara pihak Yayasan penyelenggara satuan pendidikan yang bersangkutan dengan berbagai komponen masyarakat yang tentu saja dengan syarat dan ketentuan sesuai peraturan yang berlaku. Sedangkan pelaksanaan pengembangannya yaitu peningkatan kompetensi dan profesionalisme dilakukan melalui kerja sama antara pihak Yayasan yang bersangkutan, pemerintah baik pusat maupun daerah, organisasi profesi, dan tentu saja juga melibatkan masyarakat yang dianggap memliki kompetensi sesuai yang dibutuhkan. Hal ini menunjukkan terdapat lima aspek dalam pelaksanaan manajemen pendidikan berbasis masyarakat yang salah satunya adalah agar pengelola pendidikan tidak menangani sendiri programnya, melainkan harus bermitra dengan organisasi kemasyarakatan yang lainnya (Sihombing, 2000).

Pelibatan partisipasi masyarakat di sini dilakukan untuk menjamin terpenuhinya standar Pendidik dan Tenaga Kependidikan, yaitu kriteria tentang kualifikasi akademik dan kompetensi yang dipersyaratkan bagi pendidik dan tenaga kependidikan PAUD. Pendidik anak usia dini merupakan tenaga profesional yang bertugas merencanakan, melaksanakan pembelajaran, dan menilai hasil pembelajaran, serta melakukan pembimbingan, pelatihan, pengasuhan dan perlindungan. Pendidik Anak usia dini terdiri atas guru PAUD, guru pendamping, dan guru pendamping muda. Tenaga kependidikan anak usia dini merupakan 
tenaga yang bertugas melaksanakan administrasi, pengelolaan, pengembangan, pengawasan, dan pelayanan teknis untuk menunjang proses pendidikan pada satuan dan atau program PAUD. Pendidik dan Tenaga Kependidikan anak usia dini memiliki kualifikasi akademik dan kompetensi yang dipersyaratkan, sehat jasmani, rohani/mental, dan sosial (Permana, Syafrida, 2019).

Keenam, pelibatan partisipasi masyarakat dalam pemenuhan kebutuhan sarana dan prasarana pendidikan di RA Alhilal Cikarang pada dasarnya bukan hal yang baru, yaitu menggunakan cara-cara konvensional yang biasa dan umum dilakukan dalam dunia pendidikan di mana pun di tanah air kita ini. Prosedurnya pun seperti biasa dilakukan dengan penyampaian program dalam suatu forum musyawarah atau melalui proposal yang dikirim kepada calon donatur secara personal atau melalui pimpinan lembaga kemasyarakat tertentu. Biasanya pihak yayasan bersama-sama dengan satuan pendidikan mengidentifikasi berbagai kebutuhan yang diperlukan dalam penyelenggaraan pendidikan, kemudian disusun menjadi suatu program, dan selanjutnya di bawa ke dalam forum rapat yang dihadiri berbagai unsur yang merupakan representasi keterwakilan masyarakat atau dituangkan dalam bentuk permohonan yang diajukan kepada masyarakat perorangan atau kepada para tokoh dan pimpinan lembaga sosial kemasyarakatan seperti forum masyarakat peduli pendidikan dan lain-lain.

Namun ada hal yang cukup menarik dan kiranya perlu diamati lebih seksama yaitu munculnya keikhlasan dan kesukarelaan dalam pemberian bantuan atau sumbangan tanpa merasa ada tekanan atau paksaan dari pihak manapun. Hal ini terjadi karena kuatnya rasa memiliki yang sudah terbangun sebagai dampak dari besarnya kepercayaan kepada lembaga, sehingga merasa terpanggil untuk turut serta ambil peran dalam proses pengadaan, perawatan, dan penggunannya.

Pelibatan masyarakat dalam pemenuhan standar sarana dan prasarana yang merupakan kriteria tentang persyaratan pendukung penyelenggaraan dan pengelolaan pendidikan anak usia dini secara holistik dan integratif diwujudkan melalui pemanfaatan potensi lokal. Sarana dan prasarana merupakan perlengkapan dalam penyelenggaraan dan pengelolaan kegiatan pendidikan, pengasuhan, dan perlindungan anak usia dini. Pengadaan sarana dan prasarana biasanya disesuaikan dengan jumlah anak, usia, lingkungan sosial dan budaya lokal, serta jenis layanan. Prinsip pengadaan sarana prasarana meliputi: (a) aman, bersih, sehat, nyaman, dan indah; (b) sesuai dengan tingkat perkembangan anak; (c) memanfaatkan potensi dan sumberdaya yang ada di lingkungan sekitar, dan benda lainnya yang layak pakai serta tidak membahayakan kesehatan anak.

Ketujuh, terdapat alasan yang memperkuat kesan bahwa RA Alhilal menerapkan model pengelolaan pendidikan berbasis masyarakat (community based educational management). Salah satu alasannya karena masyarakat diposisikan sebagai subyek yang turut menentukan arah dan kebijakan lembaga. Di sini terdapat sinergitas yang intens antara Yayasan selaku penyelenggara layanan pendidikan dengan masyarakat lingkungannya. Yayasan selaku penyelengara PAUD di satu pihak secara demokratis membuka lebar ruang untuk pelibatan unsur masyarakat dalam perumusan kebijakan strategis dan operasional guna pengembangan satuan pendidikan di bawah naungannya. Sementara masyarakat selaku pemangku kepentingan di pihak lain secara sukarela bahu-membahu bergotong royong mengerahkan berbagai potensi yang dimiliki baik pikiran, tenaga, dan materi secara individu maupun kolektif memberikan sumber daya yang diperlukan untuk mendukung pelaksanaan layanan pendidikan yang berkualitas. Dalam hal ini berarti apa yang dilakukan merupakan perwujudan dari semangat yang terkandung dalam system pendidikan nasional mengenai peranserta masyarakat dalam pendidikan yang menegaskan bahwa peranserta masyarakat dalam pendidikan meliputi peranserta perseorangan, kelompok, keluarga organisasi profesi, pengusaha, dan organisasi kemasyarakatan dalam penyelenggaraan dan pengendalian mutu pelayanan pendidikan. 
Selain itu secara teknis pelaksanaan manajemen pendidikan berbasis masyarakat yang diuraikan di atas sesuai dengan yang diatur dalam Peraturan Menteri Pendidikan dan Kebudayaan nomor 137 tahun 2014 yang menyebutkan bahwa standar pengelolaan PAUD merupakan pelaksanaan yang mengacu pada standar isi, proses, pendidik dan tenaga kependidikan, sarana dan prasarana, serta pembiayaan. Standar Pengelolaan Pendidikan Anak Usia meliputi perencanaan program, pengorganisasian, pelaksanaan rencana kerja, dan pengawasan. Perencanaan program merupakan penyusunan kegiatan lembaga PAUD dalam mencapai visi, misi, tujuan lembaga (Nurmiyanti \& Candra, 2019). Setiap satuan atau program memiliki kurikulum, kalender pendidikan, struktur organisasi, tata tertib, dan kode etik. Pengorganisasian merupakan pengaturan seluruh komponen untuk mencapai tujuan. (5) Pelaksanaan rencana kegiatan merupakan kegiatan pelaksanaan program kerja yang sudah direncanakan. Pengawasan meliputi pemantauan, supervisi, evaluasi, pelaporan, dan tindak lanjut hasil pengawasan guna menjamin terpenuhinya hak dan kebutuhan anak serta kesinambungan program PAUD. Program PAUD merupakan integrasi dari layanan pendidikan, pengasuhan, perlindungan, kesehatan dan gizi yang diselenggarakan dalam bentuk satuan atau program Taman Kanak-kanak (TK)/ Raudatul Athfal (RA), Bustanul Athfal (BA), Kelompok Bermain (KB), Taman Penitipan Anak (TPA), dan Satuan PAUD Sejenis (SPS).

Kaitannya dengan implementasi manajemen pendidikan berbasis masyarakat dalam penjaminan mutu PAUD adalah menjadikan pelibatan partisipasi masyarakan sebagai instrument dalam pengelolaan pendidikan demokratis. Hal ini sejalan bahwa partisipasi masyarakat adalah penciptaan lingkungan terbuka dan demokratik, di mana warga sekolah yaitu guru, siswa, karyawa, dan masyarakat yaitu orang tua, tokoh masyarakat, ilmuwan, usahawan, dan sebagainya didorong untuk terlibat secara langsung dalam penyelenggaraan pendidikan mulai dari pengeeeambilan keputusan, pelaksanaan, dan evalusinya dalam upaya peningkatan mutu pendidikan (Imam Mahali, 2016).

Kedelapan. terkait dengan pelibatan peran serta masyarakat dalam pemenuhan standar pembiayaan dapat dijelaskan bahwa selama ini pembiayaan pendidikan di RA alhilal benar-benar bertumpu pada dua sumber utama yaitu dari anggaran yang disiapkan yayasan dan dari partisipasi masyarakat sekitarnya sebagai donatur. Tidak dipungkiri memang terkadang secara insidental ada bantuan dari pemerintah tetapi biasanya tidak berupa kuncuran dana melainkan dalam bentuk program kegiatan tertentu seperti pelatihan guru. Oleh karena itu sebagai konsekwensinya adalah suatu keniscayaan agar pengelolaanya dilakukan secara transfaran dengan membuka keterlibatan masyarakat sebagai bentuk akuntabilitasnya. Masyarakat baik sebagai individu tau pun secara bersama-sama terlibat baik langsung atau pun tidak langsung dalam perencanaan, pelaksanaan, dan pengawasannya secara proporsional. Harus diakui bahwa masyarakat merupakan sumber pendapatan utama dan pemberi kontribusi paling besar dalam pemenuhan kebutuhan biaya pendidikan, baik biaya investasi, biaya operasional dan terutama biasa personal. Hal ini pada prinsipnya tidak bertentangan dengan peraturan yang berlaku sebagaimana diamanatkan dalam pasal 46 ayat 1 Undang-Undang nomor 20 tahun 2003 tentang Sistem Pendidikan Nasional yang menyatakan dengan tegas bahwa pendanaan pendidikan menjadi tanggung jawab bersama antara pemerintah, pemerintah daerah, dan masyarakat(Gustiana, 2011).

Hal di atas pada dasarnya sudah sesuai dengan semangat yang terkandung dalam Standar Nasional PAUD mengenai pembiayaan yang menyatakan bahwa komponen pembiayaan meliputi biaya operasional dan biaya personal. Biaya operasional digunakan untuk gaji pendidik dan tenaga kependidikan serta tunjangan yang melekat, penyelenggaraan program pembelajaran, pengadaan dan pemeliharaan sarana-prasarana, serta pengembangan SDM. Sedangkan biaya personal meliputi biaya pendidikan yang dikeluarkan untuk anak dalam mengikuti proses pembelajaran. Selain itu ditegaskan pula bahwa biaya operasional dan personal dapat berasal dari pemerintah pusat, pemerintah daerah, yayasan, partisipasi masyarakat, dan atau pihak lain yang tidak mengikat (Syafrida et al., 2020). 
Dengan kata lain, implentasi pendidikan berbasis masyarakat dijadikan sebagai sebuah pendekatan dalam pelaksanaan penjaminan mutu di RA Alhilal. Artinya di sini peran serta masyarakat menjadi modal utama, kalau pun tidak dikatakan satu-satunya, yang diandalkan sebagai tumpuan dalam mewujudkan target dan cita-cita kualitas pendidikannya. Ini sangat realistis jika dikaitkan dengan adanya keterbatasan kemampuan pemerintah dan yayasan penyelenggara pendidikan sebagai pihak yang paling bertanggung jawab dalam pemenuhan berbagai kebutuhan sumber daya sesuai dengan standar yang ditentukan. Pendekatan ini bisa menjadi solusi alternatif dalam memecahkan masalah peningkatan mutu yang selama ini dianggap sebagai persoalan klasik yang belum berhasil dipecahkan secara tuntas dalam pembangunan bidang pendidikan secara nasional. Hal ini sejalan dengan kebijakan pemerintah (Kemendikbud, 2017) yang menegaskan bahwa pelaksanaan penjaminan mutu pendidikan pada tingkat satuan pendidikan dilakukan dengan pendekatan pelibatan seluruh komponen satuan pendidikan (whole school approach) agar seluruh komponen satuan pendidikan Bersama-sama memiliki budaya mutu.

Optimalisasi pelibatan partisipasi masyarakat dalam upaya penjaminan mutu guna pencapaian standar mutu yang dilakukan di RA Alhilal dapat berjalan dengan baik karena didukung oleh adanya kesadaran kolektif untuk ikut ambil bagian dalam menanggung beban dan tanggung jawab masyarakat selaku pemangku kepentingan pendidikan. Hal ini tentu saja tidak lain merupakan buah dari komitmen yang kuat dalam mengemban amanat yang menjadi prinsip dalam bernegara dan bermasyarakat bahwa pendidikan menjadi tanggung jawab bersama antara orang tua, pemerintah, dan masyarakat. Hal ini berbeda dengan dinamika Implementasi MBS terdiri dari Dukungan, Penolakan, Tantangan (Isnanto \& Yustika, 2020).

Selain itu, pola manajerial yang diterapkan di RA Al Hilal juga bisa menjadi salah satu factor pengungkit yang menyebabkan optimalnya pelibatan partisipasi masyarakat tersebut. Paling tidak ada 2 strategi yang dilakukan pihak manjemen dalam hal ini yaitu: pertama, penerapan budaya transfaransi dalam pengelolaan sumber daya pendidikannya. Dalam hal ini pihak manajemen senantiasa membuka akses seluas-luasnya kepada para pemangku kepentingan untuk memperoleh informasi, memberikan masukan, dan mengawal seluruh proses pencarian, pengumpulan, dan pengawasan, serta pemanfaatan sumber daya pendidikannya . Masyarakat dalam hal ini ikut serta dalam pengambilan keputusan strategis dan melakukan kontrol guna menghindari terjadinya penyimpangan. Masyarakat diposisikan sebagai subyek dalam pengelolaan sumber daya pendidikannya. Hal ini sesuai dengan konsep yang menyatakan bahwa pendidikan harus memberdayakan dan memberi peluang serta kebebasan kepada masyarakat untuk mendesain, merencanakan, membiayai, mengelola, dan menilai apa yang diperlukan oleh masyarakat sendiri (Imam Mahali, 2016).

Terdapat beragam nilai yang saling terkait dalam penerapan budaya transfaransi di sini antara lain kepercayaan (trust), integritas, amanah, jujur, tulus dan ikhlas (Arifin et al., 2020). Kesemua nilai tadi saling berinteraksi membangun budaya keterbukaan. Umpamanya kepercayaan tumbuh dengan sendirinya ketika sang pembuat atau pelaksana kebijakan memiliki integritas tinggi, bersikap amanah, dan jujur dalam perkataan dan perbuatannya, sehingga mendorong ketulusan dan keikhlasan untuk berbuat sesuatu yang diyakininya akan menjadi amal kebajikan atau amal soleh (Katilmiş et al., 2011).

Kedua, penerapan budaya akuntabilitas publik secara efektif dalam pelaksanaan kinerjanya. Efektifnya pembudayaan akuntabilitas di sini diwarnai beragam tata nilai antara lain (1) komitmen terhadap kepentingan pendidikan masyarakat beserta pemangku kepentingan lainnya dengan sebaik-baiknya, (2) konsisten dalam melaksanakan peraturan yang berlaku serta memegang teguh kesepakan yang telah dibuat bersama-sama, (3) konsekwen dalam menanggung akibat dari setiap kebijakan yang telah dibuat, dan (4) bertanggung jawab penuh atas semua kesalahan atau penyimpangan dalam pelaksanaan kegiatannya . Komitmen yang tinggi berdampak kepada tingkat kepuasan stakeholders sehingga dapat meminimalkan munculnya keluhan, sedangkan dengan konsistensi maka 
seluruh proses dan hasilnya dapat dipertanggungjawabkan baik secara administratif atau pun secara moral. Setiap kebijakan satuan pendidikan dibuat dengan mengacu kepada peraturan yang jelas sebagai rujukannya, dan dirumuskan secara tertulis yang dituangkan ke dalam surat keputusan atau dalam bentuk standar operasional prosedur.

\section{SIMPULAN}

Implementasi manajemen pendidikan berbasis masyarakat dalam penjaminan mutu di RA Al Hilal Cikarang dilakukan melalui suatu pendekatan yaitu pelibatan partisipasi masyarakat secara optimal dalam upaya pemenuhan Standar Nasional PAUD. Sedangkan untuk mengoptimalkan pelibatan partisipasi tersebut terdapat upaya yang dilakukan dengan menggunakan dua strategi utama yaitu (1) penerapan budaya transfaransi dalam pengelolaan sumber daya pendidikan dan (2) melaksanakan budaya akuntabilitas publik secara efektif dalam pertanggungjawaban kinerja bidang akademik atau pun nonakademik.

\section{UCAPAN TERIMA KASIH}

Peneliti mengucapkan terima kasih kepada seluruh pihak yang telah membantu peneliti, khususnya kepada kepala RA dan guru juga jajaran di Yayasan Raudhatul Athfal (RA) Al Hilal Cikarang dimulai dari tahapan persiapan awal penelitian hingga laporan akhir penelitian ini.

\section{DAFTAR PUSTAKA}

Arifin, Z., Kosim, A., Muzaki, I. A., \& Permana, H. (2020). Concept and Implementation of Character Education for Urban Children and Adolescents Viewed from the Perspective of the Quran Surah Luqman Verses 12-14. 10(2), 95-102.

Baharun, H., Hefniy, H., Silviani, S., Maarif, M. A., \& Wibowo, A. (2021). Knowledge Sharing Management: Strategy for Improving the Quality of Human Resources. AL-TANZIM: Jurnal Manajemen Pendidikan Islam, 5(1), 129-139. https://doi.org/10.33650/altanzim.v5i1.1831

Budiyanti, N., Aziz, A. A., Sunandar, D., \& Erihadiana, M. (2021). Supervisi Kepala Sekolah Untuk Meningkatkan Kompetensi Pedagogik Spiritual Pendidik. Islamic Management: $\begin{array}{lllll}\text { Jurnal Manajemen } & \text { Pendidikan } & \text { Islam, } & 4(01), & \end{array}$ https:// doi.org/10.30868/im.v4i01.827

Dwikurnaningsih, Y. (2020). Implementasi Supervisi Akademik di Lembaga Pendidikan Anak Usia Dini. Jurnal Manajemen Dan Supervisi Pendidikan, 4(3), 182-190. https:// doi.org/10.17977/um025v4i32020p182

Firman, M. (2018). Policy and Implementation of Mangrove. 05(April), 14-27.

Gustiana, A. D. (2011). Pengaruh Permainan Modifikasi Terhadap Kemampuan Motorik Kasar Dan Kognitif Anak Usia Dini. Jurnal Penelitian Pendidikan, Edisi Khus(2), 154-163.

Handoko, T. H. (2011). Manajemen Personalia dan Sumber Daya Manusia. Pengantar Manajemen.

Idhayani, N., Nasir, N., \& Jaya, H. N. (2020). Manajemen Pembelajaran untuk Menciptakan Suasana Belajar Menyenangkan di Masa New Normal. Jurnal Obsesi: Jurnal Pendidikan Anak Usia Dini, 5(2), 1556-1566. https://doi.org/10.31004/obsesi.v5i2.911

Imam Mahali, A. H. (2016). Hand Book of Education Management. Pranadamedia Group.

Isnanto, I., \& Yustika, Y. (2020). Implementasi Manajemen Berbasis Sekolah (MBS) pada Kelas Awal di Kota Gorontalo. Jurnal Obsesi : Jurnal Pendidikan Anak Usia Dini, 4(2), 1087. https://doi.org/10.31004/obsesi.v4i2.514

Katilmiş, A., Ekşi, H., \& Öztürk, C. (2011). Efficiency of social studies integrated character education program. Kuram ve Uygulamada Egitim Bilimleri, 11(2), 854-859. 
Implementasi Manajemen Pendidikan Berbasis Masyarakat dalam Penjaminan Mutu Pendidikan Anak Usia Dini DOI: $10.31004 /$ obsesi.v6i2.1357

Kementerian Pendidikan dan Kebudayaan. (2018). Peraturan Menteri Pendidikan dan $\begin{array}{lllll}\text { Kebudayaan } & \text { Indonesia } & \text { No. } & 18 & \text { tahun }\end{array}$ https:// doi.org/10.1017/CBO9781107415324.004

Maiza, Z., \& Nurhafizah, N. (2019). Pengembangan Keprofesian Berkelanjutan dalam Meningkatkan Profesionalisme Guru Pendidikan Anak Usia Dini. Jurnal Obsesi : Jurnal Pendidikan Anak Usia Dini, 3(2), 356. https://doi.org/10.31004/obsesi.v3i2.196

Nurmiyanti, L., \& Candra, B. Y. (2019). Kepemimpinan Transformasional Dalam Peningkatan Mutu Pendidikan Anak Usia Dini. Al-Tanzim : Jurnal Manajemen Pendidikan Islam, 3(2), 13-24. https:// doi.org/10.33650/al-tanzim.v3i2.646

Permana, Syafrida, R. (2019). Meningkatkan keterampilan mengenal huruf hijaiyah melalui metode utsmani dan metode baghdadi.Awlady Jurnal Pendidikan Anak, 5 (2), 48-61. https://doi.org/10.24235/awlady.v5i2.4929

Permana, H., \& Syafrida, R. (2019). Peningkatan Kepercayaan Diri Anak Melalui Permainan Kucing Dan Tikus Di Tk Sayang Ibu Tahun 2019. Journal of Early Childhood Education (JECE), 1(2), 9-15. https:// doi.org/10.15408/jece.v1i2.12399

Ruslan Wahyudin, U., \& Permana, H. (2020). Education Quality Assurance Management in the Faculty of Health Science, Singaperbangsa Karawang University. KnE Social Sciences, 2020, 505-512. https:// doi.org/10.18502/kss.v4i14.7909

Safitri, A., Kabiba, K., Nasir, N., \& Nurlina, N. (2020). Manajemen Pembelajaran bagi Anak Usia Dini dalam Meningkatkan Kualitas Pembelajaran. Jurnal Obsesi: Jurnal Pendidikan Anak Usia Dini, 5(2), 1209-1220. https://doi.org/10.31004/obsesi.v5i2.811

Sihombing, U. (2000). Pendidikan Luar Sekolah Manajemen Strategi. PD. Mahkota.

Supriadi, F. J. \& D. (2001). Reformasi Pendidikan dalam Konteks Otonomi Daerah. Adi Cita.

Syafrida, R., Maryati, M., \& Permana, H. (2020). Early Childhood Education: In The Past, Present and Future. Journal of Early Childhood Care and Education, 2(2), 79. https://doi.org/10.26555/jecce.v2i2.1016

Utami, W. Y. D., Jamaris, M., \& Meilanie, S. M. (2019). Evaluasi Program Pengelolaan Lembaga PAUD di Kabupaten Serang. Jurnal Obsesi : Jurnal Pendidikan Anak Usia Dini, 4(1), 67. https://doi.org/10.31004/obsesi.v4i1.259

Wahyudin, U. R., Permana, H., \& Nurlailasari, E. (2021). Sosialisasi Model Manajemen Pendidikan Berbasis Kabupaten Karawang. 5(2).

Yanto, M. (2020). Manajemen Mutu Pendidikan Anak Usia Dini Wijaya Kusuma Rejang Lebong. Zuriah: Jurnal Pendidikan Anak Usia Dini, 1(2), 97. https://doi.org/10.29240/zuriah.v1i2.2020

Yusutria, Y. (2019). Peningkatan Mutu Pendidikan Anak Usia Dini melalui Peningkatan Profesionalitas Guru. Golden Age: Jurnal Pendidikan Anak Usia Dini, 3(1), 27-32. https://doi.org/10.29313/ga.v3i1.4828

Zubaidi. (2005). Pendidikan Berbasis Masyarakat, Upaya menawarkan Solusi Terhadap Berbagai Problem Sosial. Pustaka Belajar.

Zulkarnain, A. I., Supriadi, G., \& Saudah, S. (2020). Problematika Lembaga PAUD dalam Memenuhi Kebutuhan Tenaga Pendidik Sesuai Kualifikasi. Jurnal Obsesi: Jurnal Pendidikan Anak Usia Dini, 5(1), 14. https:// doi.org/10.31004/obsesi.v5i1.491 